\title{
Phosphorus elimination from aqueous solution using 'zirconium loaded okara' as a biosorbent
}

\author{
T.A.H. Nguyen ${ }^{a}$, H.H. Ngo ${ }^{\text {a,* }}$, W.S. Guo ${ }^{\text {a }}$, J.L. Zhou ${ }^{\text {a }}$, J. Wang ${ }^{b}$, H. Liang ${ }^{c}$, G. $^{2}{ }^{c}$

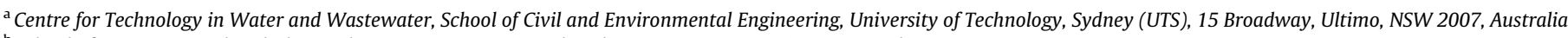 \\ ${ }^{\mathrm{b}}$ School of Environmental and Chemical Engineering, Tianjin Polytechnic University, Tianjin 300387, China \\ 'School of Municipal and Environmental Engineering, Harbin Institute of Technology, 150090, China
}

\section{H I G H L I G H T S}

- ZLO exhibited reasonably high phosphorus adsorption capacity $(44.13 \mathrm{mg} / \mathrm{g})$.

- Except pH 12, pH 2-11 had a minor effect on phosphorus retention by ZLO.

- Phosphorus removal by ZLO was rapid with the efficiency reached $95 \%$ in $30 \mathrm{~min}$.

- The adsorption process had feasible, spontaneous, and endothermic nature.

- Phosphorus was captured by ZLO predominantly as chemisorption.

\section{A R T I C L E I N F O}

\section{Article history:}

Received 19 June 2014

Received in revised form 16 July 2014

Accepted 17 July 2014

Available online 24 July 2014

\section{Keywords:}

Biosorbent

Isotherms

Kinetics

Okara

Phosphate removal

\begin{abstract}
A B S T R A C T
This work deals with the capture of phosphorus from aqueous solutions by biosorption onto zirconium loaded okara (ZLO). The batch-mode experiments were conducted to examine the effect of pH, biosorbent dose, initial phosphorus concentration, contact time, and temperature on the process. It was found that, the adsorption was most favored in the $\mathrm{pH}$ range of 2-6. The optimal doses for the adsorption, at initial phosphorus concentrations of $5,10,25,50 \mathrm{mg} / \mathrm{L}$ were $2,3,7,10 \mathrm{~g} / \mathrm{L}$, respectively. The maximum adsorption capacity of ZLO was approximately $44.13 \mathrm{mg} \mathrm{PO}_{4} / \mathrm{g}$ at $298 \mathrm{~K}$. The phosphate removal was rapid, reaching $95 \%$ in 30 min. Freundlich model best fitted the equilibrium data, while Pseudo-second order model satisfactorily described the kinetic results. Thermodynamic analysis revealed feasible, spontaneous, and endothermic nature of the process. The research would be beneficial for developing a promising, eco-friendly phosphorus biosorbent from a plentiful AWB - okara.
\end{abstract}

(c) 2014 Elsevier Ltd. All rights reserved.

\section{Introduction}

Phosphorus is essential to the development of plants, animals and the industrial manufacture (Choi et al., 2012; Karachalios, 2012; Mezenner and Bensmaili, 2009). However, due to the overexploitation, the global phosphate rock reserve is predicted to be exhausted in the next 50-100 years (Cooper et al., 2011; Eljamal et al., 2013). In another perspective, the phosphorus concentration in the aqueous medium above $0.02 \mathrm{mg} / \mathrm{L}$ can cause eutrophication,

\footnotetext{
Abbreviations: AWBs, agricultural wastes/byproducts; ZLO, zirconium loaded okara.

* Corresponding author. Address: School of Civil and Environmental Engineering, University of Technology, Sydney (UTS), P.O. Box 123, 15 Broadway, Ultimo, NSW 2007, Australia. Tel.: +61 2 95142745; fax: +61295142633.

E-mail address: ngohuuhao121@gmail.com (H.H. Ngo).
}

leading to the deterioration of water quality and threatening the life of aquatic creatures (Ismail, 2012; Jyothi et al., 2012). Therefore, the excessive amounts of phosphorus need to be removed from the aquatic medium to protect water bodies from this undesirable phenomenon, as well as pave the way to the phosphorus recovery.

A wide variety of phosphorus pollution treatment methods have been developed and applied, including chemical precipitation, biological processes, electrodialysis, reverse osmosis, ion exchange, and adsorption (Biswas et al., 2008; Boujelben et al., 2008; Xu et al., 2011a). The latter is usually a method of choice, because of being simple, effective, applicable, most appropriate for the low levels of phosphorus, favorable to the phosphorus recovery (Loganathan et al., 2014). Nevertheless, the drawbacks of commercial adsorbents (e.g. high cost, non-renewability) prevent the adsorption from widespread use in developing countries. 
In an attempt to diminish the cost of treatment, there is lately an emerging trend to use agricultural wastes/by products (AWBs) as phosphorus biosorbents (Zhang et al., 2012). Normally, AWBs are abundantly available but have low economic values. Hence, AWBs often cause the environmental burden and require disposal to mitigate their adverse impacts on the environment. Conversely, the recycling of AWBs as biosorbents for the remediation of phosphorus pollution helps the environment by reducing waste in a green way (Ismail, 2012). Moreover, it gives a chance to add values to AWBs, and to develop attractive, economical alternative to existing treatment methods (Peng et al., 2012). Nevertheless, due to the lack of binding sites for anions on their cell walls, AWBs need to be cationized via metal impregnation or quaternization reaction to efficiently remove phosphorus (Han et al., 2005; Mallampati and Valiyaveettil, 2013). Whereas many articles have been published so far, confirming the efficiency of various phosphorus AWBs adsorption systems (Benyoucef and Amrani, 2011; Biswas et al., 2008; Carvalho et al., 2011; de Lima et al., 2012; Eberhardt and Min, 2008; Karachalios, 2012; Mallampati and Valiyaveettil, 2013), the search for innovative, cost-effective, and sustainable phosphorus biosorbents is still a challenge to the adsorption researchers.

Among various methods of modifying AWBs for better phosphate removal, metal loading seems to be preferred, because of its simplicity and effectiveness. In this study, zirconium was employed as a loading metal since it has several favorable characteristics, such as strong affinity toward phosphate, high selectivity, large surface area, and chemical stability. In an earlier study conducted with different metal loaded orange waste gel (SOW), Biswas et al. (2008) explored that $\mathrm{Zr}$ (IV) loaded SOW demonstrated a superior adsorption capacity $(174.68 \mathrm{mg} / \mathrm{g})$ when compared to those loaded with $\mathrm{La}(\mathrm{III})$ or $\mathrm{Ce}(\mathrm{III})$ or $\mathrm{Fe}(\mathrm{III})(42.72 \mathrm{mg} / \mathrm{g}$ for all three gels). Similarly, in the previous paper, zirconium loaded okara (ZLO) exhibited better adsorption capacity of phosphate $(47.88 \mathrm{mg} / \mathrm{g})$ than iron/zirconium loaded okara - IZLO (40.96 $\mathrm{mg} / \mathrm{g}$ ) and iron loaded okara - ILO $(16.39 \mathrm{mg} / \mathrm{g}$ ) (Nguyen et al., 2014 DOI: http://dx.doi.org/10.1016/j.biortech.2014.06.075).

The results indicate that $\mathrm{Zr}(\mathrm{IV})$ has the stronger affinity toward phosphate than other metal ions used for metal loading of AWBs. While $\mathrm{La}(\mathrm{III})$ and $\mathrm{Fe}(\mathrm{III})$ was found to be vigorously released from metal loaded biosorbents into aqueous solutions during operation, no $\mathrm{Zr}(\mathrm{IV})$ leakage could be detected (Biswas, 2008; Mallampati and Valiyaveettil, 2013; Nguyen et al., 2013). Due to its chemical stability during operation, $\mathrm{Zr}$ (IV) can be used as a metal loading without any harmful effects on the aquatic life or public health. The high cost of $\mathrm{Zr}(\mathrm{IV})$ salts can be considered as a limitation that currently exists. However, this drawback can be overcome once the $\operatorname{Zr}(\mathrm{IV})$ loaded biosorbents can be recycled and used sustainably. These findings prove that $\mathrm{Zr}(\mathrm{IV})$ can be used as a promising loading metal for modification of AWBs.

Okara, known as soybean milk residue, soy pulp, soy fines, bean mash, bean curd dregs, is a byproduct of soy beverage and tofu production. The production of every $1000 \mathrm{~L}$ of soy beverage can result in $250 \mathrm{~kg}$ of okara (Soy 20/20, 2005). Accordingly, it is estimated that, approximately 14 million tons of okara are generated worldwide annually (Nguyen et al., 2013). Due to the rapid degradation, okara needs to be dried or frozen for further use in food. However, this is costly because of intensive use of energy and special equipment requirement. Therefore, okara is mostly dumped or burned as waste, posing the environmental concern (Li et al., 2012). In this work, okara was used as a substrate to develop an innovative biosorbent for phosphorus removal because of its dominant advantages, such as easy acquiring, abundant availability enough for large scale utilization, low cost, insolubility in water, non-toxicity. Additionally, the existence in large amounts of hydroxyl and carboxyl groups on its cell walls makes okara easily and efficiently involve in chemical modifications (Benyoucef and Amrani, 2011). Moreover, okara has phosphorous inside (396-444 mg P/100 g dry matter), enabling the phosphorous recovery from both original okara and waste water (Li et al., 2012). Eventually, to the best of the author's knowledge, the use of okara as a phosphorus biosorbent has never been reported in the previous studies.

In a previous paper, we have made a comparison of three kinds of metal loaded okara. Zirconium loaded okara (ZLO) was proven to be superior to iron/zirconium loaded okara (IZLO) and iron loaded okara (ILO), with respect to adsorption, desorption, reusability and stability. Conversely, ILO and IZLO exhibited several drawbacks, as thus demonstrating unsuitable when used as phosphate biosorbents. As the next stage, the present study extensively investigates 'zirconium loaded okara' as a selected biosorbent, with the emphasis has been placed on kinetics, isotherms and thermodynamics studies. In doing so, batch-mode experiments were conducted to identify the effect of $\mathrm{pH}$, adsorbent dose, initial phosphorus concentration, contact time and temperature on the retention of phosphorus by ZLO. The adsorption isotherms, kinetics, and thermodynamics were analyzed using nonlinear regression method in Curve Expert Professional 2.0.4. The results revealed the sorption mechanisms and nature, along with provided useful information for designing and operating the phosphorus - ZLO adsorption scheme in the future. Hence, this study has both theory and practical values.

\section{Methods}

\subsection{Materials}

\subsubsection{Biosorbent}

The fresh okara was collected from soybean milk production at the family with Lumina glass blender (Model No BL-805C). Every four liters of soybean milk made can result in one $\mathrm{kg}$ of fresh okara. To eliminate the residual milk, the pristine okara was washed with tap and distilled water on a $300 \mu \mathrm{m}$ sieve. After being dried in the oven at $105^{\circ} \mathrm{C}$ for $24 \mathrm{~h}$, it was cooled down to the ambient condition and kept in a glass bottle for further chemical treatments.

ZLO as a modified biosorbent was developed by a two-step pretreatment of okara with $\mathrm{NaOH}$ and $\mathrm{Zr}(\mathrm{IV})$ salt. Firstly, the dried raw okara was impregnated in $0.05 \mathrm{M} \mathrm{NaOH}$ solution to enhance its metal capture ability (solid/liquid ratio: $1 \mathrm{~g} / 20 \mathrm{ml}, 120 \mathrm{rpm}$, $25^{\circ} \mathrm{C}, 24 \mathrm{~h}$ ). Then, $\mathrm{NaOH}$ treated okara was saturated with $0.25 \mathrm{M} \mathrm{Zr}(\mathrm{IV})$ solution at the above conditions. Due to the cationization, $\mathrm{Zr}(\mathrm{IV})$ loaded okara can efficiently remove phosphate species from aqueous solutions.

\subsubsection{Adsorbate}

Analytical grade chemicals used in this study was provided by Chem supply, Australia. The stock solution of phosphorus ( $1000 \mathrm{mg} / \mathrm{L}$ ) was prepared by dissolving $4.58 \mathrm{~g}$ of disodium hydrogen phosphate $\left(\mathrm{Na}_{2} \mathrm{HPO}_{4}\right)$ in a $1000 \mathrm{ml}$ of milli-Q water. The working phosphorus solutions were made afterward by appropriate dilution of the stock solution with milli-Q water. The solutions of $0.05 \mathrm{M} \mathrm{NaOH}$ and $0.25 \mathrm{M} \mathrm{Zr}(\mathrm{IV})$ were produced by liquefying proper amounts of sodium hydroxide $(\mathrm{NaOH})$ and zirconyl chloride octahydrate $\left(\mathrm{ZrOCl}_{2} .8 \mathrm{H}_{2} \mathrm{O}\right)$ in the milli-Q water.

\subsection{Methods}

\subsubsection{Analytical method}

The phosphorus concentration in the solutions was determined using molybdenum blue method on Spectroquant ${ }^{\circledR}$ NOVA 60 machine. The phosphorus adsorption capability $(\mathrm{mg} / \mathrm{g}$ ) was calculated from the changes in the phosphorus concentrations before and after adsorption: 
$q_{e}=\frac{\left(C_{i}-C_{e}\right) * V}{m}$

where $C_{i}$ and $C_{e}$ are the initial and equilibrium phosphorus concentrations, respectively $(\mathrm{mg} / \mathrm{L}) ; V$ is the volume of the solution $(\mathrm{L}) ; m$ represents the dry weight of the metal loaded okara powder (g). Experiments were implemented in the duplicate, and data represented the mean values. The highest deviation was $5 \%$.

\subsubsection{Isotherm and kinetic parameters calculation method}

Isotherm and kinetic parameters are usually calculated using linear regression method in Microsoft Excel. However, there are several types of isotherm and kinetic equations in the linear form. This leads to a difficulty in comparing the results of different studies in case of lacking information on the type of equations applied. On the other hand, the nonlinear regression method in Curve Expert Professional 2.0.4 employed in this study has resulted in the unique values and hence enabling the comparison with other studies.

\subsection{Batch mode experiment setup}

\subsubsection{Effect of process parameters}

The effect of solution $\mathrm{pH}$ on the phosphorus biosorption onto ZLO was evaluated by varying the solution $\mathrm{pH}$ from 2 to 12 , while maintaining other process parameters constant. $0.5 \mathrm{~g}$ of ZLO was added to $50 \mathrm{~mL}$ of phosphorus solution of $50 \mathrm{mg} / \mathrm{L}$ in a series of $250 \mathrm{~mL}$ Erlenmeyer flasks. The parafilm covered flasks were put on a shaker at $120 \mathrm{rpm}, 298 \mathrm{~K}$ for $24 \mathrm{~h}$ to attain equilibrium. The suspensions were filtered through Whatman ${ }^{\mathrm{TM}} 1822-047$ Grade GF/C filter paper (diameter: $4.7 \mathrm{~cm}$, pore size: $1.2 \mu \mathrm{m}$ ) and filtrates were used for phosphorus measurement.

To determine the effect of the biosorbent dose on the phosphorus removal by ZLO, the experiment was performed at several biosorbent doses $(1,2,3,5,7,10,12 \mathrm{~g} / \mathrm{L})$. Different amounts of ZLO (0.05-0.6 g) were added into a series of flasks filled with $50 \mathrm{~mL}$ of phosphorus solution of $50 \mathrm{mg} / \mathrm{L}$ at natural $\mathrm{pH}$. The flasks were agitated on a shaker at $120 \mathrm{rpm}, 298 \mathrm{~K}$ for $24 \mathrm{~h}$. The sampling and analytical procedures were similar to those described for investigating the effect of $\mathrm{pH}$. For a real application purpose, the experiment was repeated at different phosphorus concentrations $(5,10,25 \mathrm{mg} / \mathrm{L})$.

\subsubsection{Adsorption isotherms}

The isotherm studies were performed by mixing $0.5 \mathrm{~g}$ ZLO with $50 \mathrm{~mL}$ solution of various phosphorus concentrations $(10,25,50$, $100,150,200,300,400,500 \mathrm{mg} / \mathrm{L}$ ) in a series of conical flasks. The initial $\mathrm{pH}$ values were kept natural. The suspensions were shaken at $120 \mathrm{rpm}, 298 \mathrm{~K}$ for $24 \mathrm{~h}$ in a thermostatic shaker to ensure the equilibrium was fully reached. After filtration through Whatman ${ }^{\mathrm{TM}} 1822-047$ Grade $\mathrm{GF} / \mathrm{C}$ filter paper (diameter: $4.7 \mathrm{~cm}$, pore size: $1.2 \mu \mathrm{m}$ ), the filtrates were analyzed to determine phosphorus concentrations. The adsorption isotherm data were fitted to Langmuir, Freundlich, and Temkin models.

\subsubsection{Adsorption kinetics}

Phosphorus biosorption kinetics by ZLO was examined by conducting experiments at a given initial phosphorus concentration and a specific biosorbent dose. The $\mathrm{pH}$ of solutions was kept neutral. The adsorption reaction was facilitated at $120 \mathrm{rpm}$ and $298 \mathrm{~K}$, using a thermostatic shaker. At the different intervals $(0.25,0.5,0.75,1.0,1.5,2,3,4,5,6 \mathrm{~h})$, the samples were taken and filtered through Whatman ${ }^{\mathrm{TM}} 1822-047$ Grade GF/C filter paper (diameter: $4.7 \mathrm{~cm}$, pore size: $1.2 \mu \mathrm{m}$ ). The filtrates were analyzed to determine phosphorus concentrations. For comparison purpose, experiment were repeated for different initial phosphorus concen- trations $(5,10,25,50 \mathrm{mg} / \mathrm{L})$ with corresponding optimal doses $(2$, $3,7,10 \mathrm{~g} / \mathrm{L})$ or a given dose $(10 \mathrm{~g} / \mathrm{L})$ of the biosorbent. The data were fitted to three common kinetic models including Pseudo-first order, Pseudo-second order, and Intra-particle diffusion.

\subsubsection{Adsorption thermodynamics}

The effect of temperature on the biosorption of phosphorus onto ZLO was evaluated by performing isotherm experiments at 298,308 , and $318 \mathrm{~K}$. The amounts of $0.5 \mathrm{~g}$ ZLO were added to several $250 \mathrm{~mL}$ Erlenmeyer flasks containing $50 \mathrm{~mL}$ of solution of different phosphorus concentrations (10-500 mg/L). The $\mathrm{pH}$ of suspensions was kept as natural. After being covered with parafilm, the flasks were shaken at $120 \mathrm{rpm}$ in a thermostatic shaker to keep the reaction temperature at 298,308 , and $318 \mathrm{~K}$. At the end of the contact time $(24 \mathrm{~h})$, the suspensions were filtered with Whatman ${ }^{\mathrm{TM}}$ 1822-047 Grade GF/C filter paper (diameter: $4.7 \mathrm{~cm}$, pore size: $1.2 \mu \mathrm{m}$ ), and the filtrates were analyzed to identify phosphorus contents.

\section{Results and discussion}

\subsection{Effect of process parameters}

\subsubsection{Effect of $p H$}

The solution $\mathrm{pH}$ can affect the chemical state of binding sites on ZLO, the dissociation of phosphate species in aqueous solutions, and the affinity of phosphate species towards binding sites. Evidently, pH plays an important role in the phosphate biosorption, and hence requiring case-by-case examination. It was found that, the phosphate removal by ZLO was most favored in $\mathrm{pH}$ range of $2-6$, with the efficiency higher than $98 \%$. This can be attributed to the dominance of $\mathrm{H}_{2} \mathrm{PO}_{4}^{-}$and $\mathrm{HPO}_{4}^{2-}$ species in the acidic medium. Due to their strong affinity toward binding sites, the phosphate capture was boosted by replacement of $\mathrm{OH}^{-}$ions from ZLO surface (Mallampati and Valiyaveettil, 2013). The augmentation in the solution $\mathrm{pH}$ from 2 to 11 led to the decrease of the phosphate removal by almost $10 \%$. This is attributed to the strong competition for the binding sites between phosphate species and $\mathrm{OH}^{-}$anions in the alkaline medium (Ismail, 2012; Riahi et al., 2009). Particularly, a dramatic decline in the phosphate removal percentage (50\%) was caused by an increase in the solution $\mathrm{pH}$ from 11 to 12 . This might have happened that, at $\mathrm{pH}>11, \mathrm{HPO}_{4}^{2-}$ and $\mathrm{PO}_{4}^{3-}$ species were prevalent. Their weak affinity toward adsorption sites caused by their strong competition with $\mathrm{OH}^{-}$anions in the alkaline medium hampered the process (Benyoucef and Amrani, 2011; Biswas et al., 2008; Zhang et al., 2012). Bearing the facts in mind, it can be concluded that, except $\mathrm{pH} 12$, the $\mathrm{pH}$ range of 2-11 demonstrated a minor effect on the phosphorus retention by ZLO. Due to the high effectiveness in a wide $\mathrm{pH}$ range, ZLO has an appreciable advantage over other biosorbents when used in the actual application. These results fit well with the findings reported by Xu et al. (2011a,b) and Zhang et al. (2012), who revealed that optimal pH values for the phosphate sorption onto giant reed and sugarcane bagasse were of $5-10$ and of $4-11$, respectively.

\subsubsection{Effect of biosorbent dose}

Fig. 1 shows the impact of the biosorbent dose on the retention of phosphorus by ZLO. As shown in Fig. 1, the extent of phosphorus removal increased from 62.5 to $100 \%$ with elevating ZLO dose from 1 to $2 \mathrm{~g} / \mathrm{L}$, at the initial phosphorus concentration $\left(C_{i}\right)$ of $5 \mathrm{mg} \mathrm{P} / \mathrm{L}$. Similarly, the phosphorus elimination by ZLO was enhanced by $62.63,79.35$, and $84.50 \%$, as a result of an increase of ZLO dose from 1 to $3 \mathrm{~g} / \mathrm{L}\left(C_{i}=10 \mathrm{mg} \mathrm{P} / \mathrm{L}\right), 1-7 \mathrm{~g} / \mathrm{L}\left(C_{i}=25 \mathrm{mg} \mathrm{P} / \mathrm{L}\right)$, and $1-10 \mathrm{~g} / \mathrm{L}$ $\left(C_{i}=50 \mathrm{mg} \mathrm{P} / \mathrm{L}\right)$, respectively. The enhanced phosphorus removal percentage at higher ZLO dose can be ascribed to more adsorption 


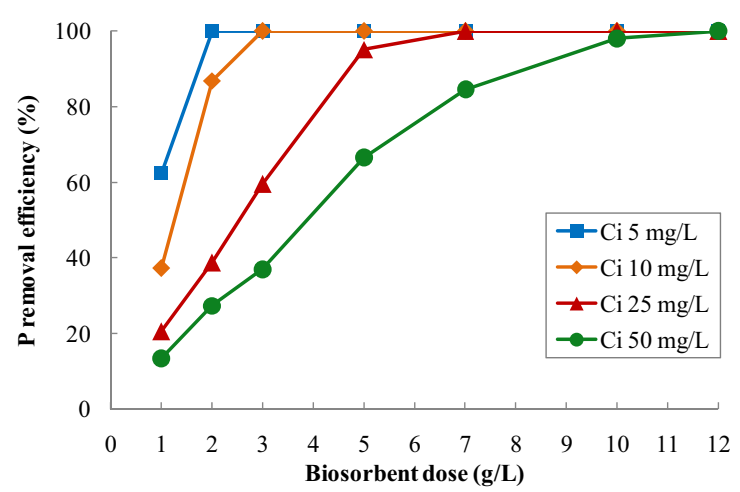

Fig. 1. Effect of biosorbent dose on phosphorus biosorption onto ZLO $\left(C_{i}: 5,10,25\right.$, $50 \mathrm{mg}$ P/L, 120 rpm, 24 h, $298 \mathrm{~K}$, biosorbent dose: 1, 2, 3, 5, 7, 10, 12 g/L).

sites or larger total surface area (Yue et al., 2010; Zhang et al., 2012). However, the removal percentage remains constant with further increase in ZLO dose. This is possibly due to the resistance to mass transfer of phosphorus from solution to ZLO surface (Ismail, 2012; Mezenner and Bensmaili, 2009). Therefore, for different initial phosphorus concentrations of $5,10,25,50 \mathrm{mg} / \mathrm{L}$, the optimal ZLO doses were determined as $2,3,7,10 \mathrm{~g} / \mathrm{L}$, respectively. In view of practical application, at a given initial phosphorus concentration, for the same level of phosphorus removal, the lower the dose is required, the more efficient the adsorbent is. In the light of this, the results attained in this study are even better than those reported by Yue et al. (2010). The authors claimed that, 98\% of phosphorus was removed with modified giant reed at the dose of $16 \mathrm{~g} / \mathrm{L}$, for the initial phosphorus concentration of $50 \mathrm{mg} / \mathrm{L}$.

\subsection{Adsorption isotherms}

Isotherm study is essential for elucidating the adsorption ability of a given biosorbent, and searching for most appropriate isotherm models that will be applied in the system design (Benyoucef and Amrani, 2011; Biswas et al., 2008; Mezenner and Bensmaili, 2009). In the present study, it was found that, the absorbed phosphorus amount $\left(q_{e}\right)$ increased with growing equilibrium phosphorus concentrations $\left(C_{e}\right)$, and got level off later. This can be ascribed to the less available phosphorus binding sites at higher equilibrium phosphorus concentrations (Benyoucef and Amrani, 2011). Based on the stable values of $q_{e}$ at the plateau section of the plot of $q_{e}$ and $C_{e}$, the maximum adsorption capacity $\left(q_{m}\right)$ of ZLO at $298 \mathrm{~K}$ was determined to be $14.4 \mathrm{mg} \mathrm{P} / \mathrm{g}(\sim 44.13 \mathrm{mg} \mathrm{PO} / \mathrm{g})$. Similarly, the $q_{m}$ of ZLO at 308 and $318 \mathrm{~K}$ were found to be $14.70 \mathrm{mg} \mathrm{P} / \mathrm{L}$

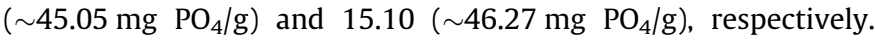
These results are equal to or even better than those of many biosorbents and commercial adsorbents listed in Table 1 . In a previous study carried out with zirconium loaded orange waste gel, Biswas et al. (2008) explored that the retention of phosphate onto $\mathrm{Zr}$ (IV) loaded orange waste (SOW) gel was possibly due to the ligand exchange mechanism, which occurred between $\mathrm{PO}_{4}^{3-}$ ions in the solution and $\mathrm{OH}^{-}$ions coordinated with the $\mathrm{Zr}(\mathrm{IV})$ ions loaded on the SOW gels. The authors explained that loaded zirconium ions could be easily converted into hydrated forms e.g. $\left[\mathrm{Zr}_{4}(\mathrm{OH})_{8}\left(\mathrm{H}_{2} \mathrm{O}\right)_{16}\right]^{8+}$, and $\left[\mathrm{Zr}_{8}(\mathrm{OH})_{20}\left(\mathrm{H}_{2} \mathrm{O}\right)_{24}\right]^{12+}$ species, with the abundant amounts of $\mathrm{OH}^{-}$ions and $\mathrm{H}_{2} \mathrm{O}$ molecules. During the hydrolysis, $\mathrm{H}_{2} \mathrm{O}$ molecules were deprotonated by releasing $\mathrm{H}^{+}$ions to form exchangeable $\mathrm{OH}^{-}$ions, which could be replaced by $\mathrm{PO}_{4}^{3-}$ ions. It is evident that, zirconium plays a key role in the phosphate removal by zirconium loaded orange waste (SOW) gel. However, the amount of $\operatorname{Zr}(\mathrm{IV})$ deposited on biosorbents depends on the binding ability, and thus nature of the materials used as substrate (orange waste gel). Similarly, the superior phosphate adsorption
Table 1

The maximum $\mathrm{PO}_{4}$ adsorption capacity of ZLO in comparison with various biosorbents and commercial adsorbents.

\begin{tabular}{|c|c|c|}
\hline Adsorbent & $\begin{array}{l}q_{m} \\
\left(\mathrm{mg} \mathrm{PO}_{4} / \mathrm{g}\right)^{\mathrm{d}}\end{array}$ & Reference \\
\hline Coir pith $(\mathrm{N})^{\mathrm{a}}$ & 4 & Krishnan and Haridas (2008) \\
\hline Juniper fiber $(\mathrm{M})^{\mathrm{b}}$ & 7 & Han et al. (2005) \\
\hline $\begin{array}{l}\text { Posidonia oceanica (L.) fibers } \\
\quad(\mathrm{N})\end{array}$ & 7 & Wahab et al. (2011) \\
\hline Eggshell (M) & 11 & Mezenner and Bensmaili (2009) \\
\hline Date palm fibers $(\mathrm{N})$ & 13 & Riahi et al. (2009) \\
\hline Pine sawdust char (M) & 15 & Peng et al. (2012) \\
\hline Aspen wood $(\mathrm{M})$ & 17 & Eberhardt and Min (2008) \\
\hline Apple peels (M) & 20 & $\begin{array}{l}\text { Mallampati and Valiyaveettil } \\
\text { (2013) }\end{array}$ \\
\hline Sugarcane bagasse (M) & 21 & Zhang et al. (2012) \\
\hline Palm surface fibers $(\mathrm{N})$ & 26 & Ismail (2012) \\
\hline Granular date stones (N) & 26 & Ismail (2012) \\
\hline Aluminum oxide $(C)^{c}$ & 35 & Peleka and Deliyanni (2009) \\
\hline Zirconium ferrite (C) & 40 & Biswas et al. (2008) \\
\hline Dowex (C) & 40 & Anirudhan and Senan (2011) \\
\hline Orange waste gel (M) & 43 & Biswas et al. (2007) \\
\hline Okara(M) & 44 & This study \\
\hline Wheat straw (M) & 46 & Xu et al. (2010) \\
\hline Cotton stalk (M) & 52 & Xu et al. (2011b) \\
\hline Hydrotalcite (C) & 60 & Anirudhan and Senan (2011) \\
\hline Giant reed $(\mathrm{M})$ & 61 & Yue et al. (2010) \\
\hline Wheat stalk (M) & 61 & Xu et al. (2011b) \\
\hline Coir pith (M) & 71 & Krishnan and Haridas (2008) \\
\hline Aleppo pine sawdust (M) & 116 & Benyoucef and Amrani (2011) \\
\hline $\begin{array}{l}\text { Zirconium loaded } \\
\quad \text { MUROMAC }(\mathrm{C})\end{array}$ & 132 & Biswas et al. (2008) \\
\hline Sugar cane bagasse fiber (M) & 152 & Carvalho et al. (2011) \\
\hline Orange waste gel (M) & 175 & Biswas et al. (2008) \\
\hline Coconut shell fibers (M) & 200 & de Lima et al. (2012) \\
\hline Wood residues (M) & 206 & Karachalios (2012) \\
\hline
\end{tabular}

capacity of ZLO to other biosorbents can be ascribed to the strong binding ability of okara with $\operatorname{Zr}($ IV) and high affinity of $\operatorname{Zr}($ IV) toward phosphate ions.

To determine isotherm parameters along with the most suitable isotherm model, the experimental data obtained with ZLO at 298, $308,318 \mathrm{~K}$ were fitted with Langmuir, Freundlich, and Temkin models, using the Curve Expert Professional 2.0.4. Langmuir model stands for monolayer adsorption, assuming that adsorption takes place at a specific number of adsorption sites, each site is occupied by one adsorbate molecule, all sites are the same, and there is no interaction between adsorbed molecules. Langmuir isotherm model in nonlinear form (Kumar et al., 2010) is given by the Eq. (2):

$q_{e}=\frac{q_{m} K_{L} C_{e}}{1+K_{L} C_{e}}$

where $q_{m}(\mathrm{mg} / \mathrm{g})$ is the maximum mass of phosphates adsorbed per unit weight of ZLO when the surface of ZLO is entirely covered by monolayer of phosphate ions, $K_{L}(\mathrm{~L} / \mathrm{mg})$ is Langmuir constant associated with the affinity of binding sites on ZLO surface to the phosphate ions, $q_{e}(\mathrm{mg} / \mathrm{g})$ is the quantity of phosphate adsorbed onto $1 \mathrm{~g}$ of ZLO under equilibrium condition, $C_{e}(\mathrm{mg} / \mathrm{L})$ is the equilibrium phosphate concentration.

The Langmuir isotherm is characterized by the separation factor $\left(R_{L}\right)$ (Mallampati and Valiyaveettil, 2013) and is expressed by the Eq. (3).

$R_{L}=\frac{1}{1+K_{L} C_{i}}$

where $K_{L}(\mathrm{~L} / \mathrm{mg})$ represents Langmuir constant and $C_{i}$ indicates the initial concentration of phosphorus. 
Table 2

Isotherms and kinetics parameters by non-linear regression method for the biosorption of phosphorus onto ZLO.

\begin{tabular}{|c|c|c|c|c|c|c|c|}
\hline \multirow[t]{2}{*}{ Isotherm parameters } & \multicolumn{3}{|c|}{ Temperature $(K)$} & \multirow[t]{2}{*}{ Kinetic parameters } & \multicolumn{3}{|c|}{ Initial P concentration $(\mathrm{mg} / \mathrm{L})$} \\
\hline & 298 & 308 & 318 & & 10 & 25 & 50 \\
\hline 1. Langmuir & & & & 1. Pseudo-first order & & & \\
\hline$q_{m, \text { exp. }}\left(\mathrm{mg} \mathrm{g}^{-1}\right)$ & 14.400 & 14.700 & 15.100 & $q_{e, \text { exp. }}\left(\mathrm{mg} \mathrm{g}^{-1}\right)$ & 1.060 & 2.560 & 4.540 \\
\hline$q_{m, \text { cal. }}\left(\mathrm{mg} \mathrm{g}^{-1}\right)$ & 14.039 & 14.608 & 15.321 & $q_{e, \text { cal. }}\left(\mathrm{mg} \mathrm{g}^{-1}\right)$ & 1.055 & 2.479 & 4.232 \\
\hline$K_{L}\left(\mathrm{~L} \mathrm{mg}^{-1}\right)$ & 0.065 & 0.069 & 0.062 & $\mathrm{~K}_{1 \mathrm{p}}\left(\mathrm{h}^{-1}\right)$ & 5.852 & 2.194 & 1.221 \\
\hline$R_{L}($ at $C i 50-500 \mathrm{mg} / \mathrm{L})$ & $0.030-0.235$ & $0.028-0.225$ & $0.031-0.244$ & $r^{2}$ & 0.9997 & 0.980 & 0.975 \\
\hline$r^{2}$ & 0.885 & 0.894 & 0.894 & 2. Pseudo-second order & & & \\
\hline 2. Freundlich & & & & $q_{e, \text { exp. }}\left(\mathrm{mg} \mathrm{g}^{-1}\right)$ & 1.060 & 2.560 & 4.540 \\
\hline$K_{F}\left(\mathrm{~L} \mathrm{~g}^{-1}\right)$ & 3.630 & 4.080 & 4.371 & $q_{e, \text { cal. }}\left(\mathrm{mg} \mathrm{g}^{-1}\right)$ & 1.091 & 2.718 & 4.916 \\
\hline$n$ & 4.124 & 4.383 & 4.513 & $K_{2 p}\left(\mathrm{~g} \mathrm{mg}^{-1} \mathrm{~h}^{-1}\right)$ & 13.345 & 1.224 & 0.3005 \\
\hline$r^{2}$ & 0.981 & 0.977 & 0.978 & $r^{2}$ & 0.993 & 0.997 & 0.989 \\
\hline 3. Temkin & & & & 3. Intra particle diffusion & & & \\
\hline$q_{m}\left(\mathrm{mg} \mathrm{g}^{-1}\right)$ & 1.684 & 1.661 & 1.608 & $k_{p}\left(\mathrm{mg} \mathrm{g}^{-1} \mathrm{~h}^{-0.5}\right)$ & 0.275 & 0.884 & 1.465 \\
\hline$K_{T}$ & 10.003 & 15.149 & 24.891 & C & 0.577 & 0.842 & 1.226 \\
\hline$r^{2}$ & 0.978 & 0.982 & 0.974 & $r^{2}$ & 0.439 & 0.758 & 0.879 \\
\hline
\end{tabular}

The Freundlich model represents non-ideal adsorption, with multi adsorption sites and heterogeneous surfaces. It is based on the assumption that active binding sites are occupied first and the binding ability declines with an increase in the site occupation. Freundlich isotherm model in nonlinear form (Boujelben et al., 2008) is expressed by the Eq. (4):

$q_{e}=K_{f}\left(C_{e}\right)^{1 / n}$

where $K_{f}(\mathrm{~L} / \mathrm{g})$ and $n$ are Freundlich constants, indicating the adsorption capacity and adsorption intensity, respectively.

Temkin isotherm model (Benyoucef and Amrani, 2011) in nonlinear form can be expressed in the Eq. (5):

$q_{e}=q_{m} \ln \left(K_{T} C_{e}\right)$

where $q_{m}$ represents the adsorption capacity and $K_{T}$ is indicator for the adsorption intensity, respectively.

The isotherm parameters of three models obtained at 298, 308, and $318 \mathrm{~K}$ are listed in Table 2, while the fitting curves to three models are presented in Fig. 2. As shown in Table 2, the correlation coefficients $\left(r^{2}\right)$ achieved at $298 \mathrm{~K}$ for Langmuir, Freundlich, Temkin models were $0.885,0.981$, and 0.978 , respectively. According to the $r^{2}$ values, both Freundlich and Temkin models yielded satisfactory fit to the experimental data. Compared with Freundlich model, Langmuir exhibited much poorer fit, as shown by a substantially lower value of $r^{2}$. The results suggest the heterogeneous surface of ZLO and the multilayer nature of the biosorption. These are consistent with earlier reports for different phosphorus sorption systems, which were performed with Aleppo pine sawdust (Benyoucef and Amrani, 2011), aspen wood fiber (Eberhardt et al., 2006), and biomass char (Peng et al., 2012). It can be noted

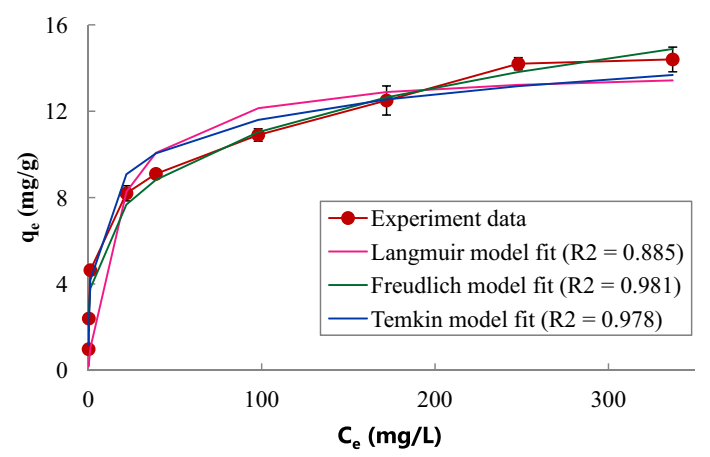

Fig. 2. The fitting of isotherm models to phosphorus biosorption onto ZLO $\left(C_{i} 10-500 \mathrm{mg} \mathrm{P} / \mathrm{L}\right.$, dose $\left.10 \mathrm{~g} / \mathrm{L}, 120 \mathrm{rpm}, 24 \mathrm{~h}, 298 \mathrm{~K}\right)$. that, the values of $n>1$ indicate the favorable biosorption. This is supported by the value of Langmuir separation factors $\left(R_{L}\right)$, which was in the range of $0<R_{L}<1$ for all cases. Furthermore, both $K_{F}$ and $\mathrm{n}$ are observed reaching their highest values at $318 \mathrm{~K}$. This showed that the adsorption capacity and the affinity between ZLO and phosphorus were boosted by elevating temperatures, and hence the biosorption nature was endothermic.

\subsection{Adsorption kinetics}

Kinetic study provides information on the adsorption rate, which is essential for system design and real application (Ismail, 2012; Peng et al., 2012). Furthermore, it helps to reveal the adsorption mechanisms (Mallampati and Valiyaveettil, 2013; Mezenner and Bensmaili, 2009). Consequently, kinetic study of the phosphorus adsorption from aqueous solutions plays an important role in the treatment of phosphorus pollution.

The kinetics for the biosorption of phosphorus onto ZLO at diverse initial phosphorus concentrations $(5,10,25,50 \mathrm{mg} / \mathrm{L})$ and a specific dose of biosorbent $(10 \mathrm{~g} / \mathrm{L})$ is shown in Fig. 3a. It can be seen that, the biosorption was very fast in the beginning, and then it slowed down and reached equilibrium. After the first $0.5 \mathrm{~h}$, almost $40 \%$, more than $60 \%, 90 \%$ and $95 \%$ of phosphorus was captured onto ZLO at initial phosphorus concentrations of $50,25,10,5 \mathrm{mg} / \mathrm{L}$, respectively. It suggests that, the lower the initial phosphorus concentration, the faster the biosorption could occur.

Kinetic curves of several initial phosphorus concentrations (5, $10,25,50 \mathrm{mg} / \mathrm{L})$ and optimal doses of biosorbent $(2,3,5,7 \mathrm{~g} / \mathrm{L})$ are presented in Fig. 3b, which showed that 2, 3, 4, 5 h was necessary to ensure the equilibrium was completely reached, respectively. As illustrated by Fig. 3a and b, for the initial phosphorus concentration of $10 \mathrm{mg} / \mathrm{L}, 3 \mathrm{~h}$ was required to remove $80 \%$ phosphorus, with the biosorbent dose of $3 \mathrm{~g} / \mathrm{L}$, while the removal efficiency of $95 \%$ could be attained with the dose of $10 \mathrm{~g} / \mathrm{L}$ in only $0.5 \mathrm{~h}$. This means that the reaction time could be shortened by applying higher doses. It would be useful for designing fix bed column experiments and large scale application.

To date, numerous mathematical models have been developed and applied in the kinetic study. Nevertheless, only appropriate models could satisfy experimental data and explain rational sorption mechanisms (Benyoucef and Amrani, 2011). In the present study, the experimental data of different initial phosphorus concentrations $(10,25,50 \mathrm{mg} / \mathrm{L})$ and a given dose of biosorbent $(10 \mathrm{~g} / \mathrm{L})$ were fitted with three well-known kinetic models to explore the major adsorption mechanisms as well as to predict 
(a)

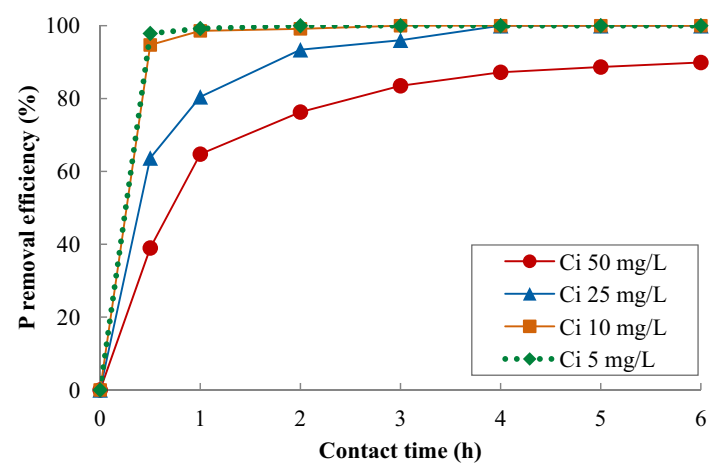

(b)

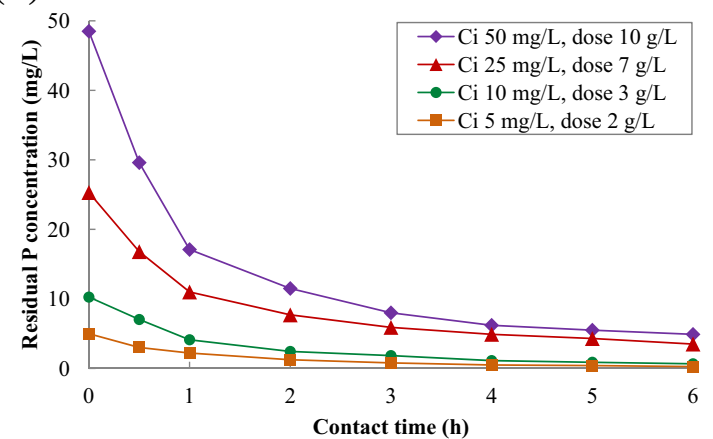

Fig. 3. Kinetic curves of phosphorus biosorption onto ZLO (3a. at different initial phosphorus concentrations and a given biosorbent dose; and $3 \mathrm{~b}$. at different initial phosphorus concentrations and optimal biosorbent doses).

the adsorption rates. The Pseudo-first order and Pseudo-second order models based on equilibrium adsorption capacity (Behnamfard and Salarirad, 2009) can be expressed by Eqs. (6) and (7):

$q_{t}=q_{e}\left[1-\exp \left(-k_{1 p} t\right)\right]$

$q_{t}=\frac{k_{2 p} q_{e}^{2} t}{1+q_{e} k_{2 p} t}$

The Weber-Morris diffusion model (Benyoucef and Amrani, 2011; Ismail, 2012; Kumar et al., 2010) is given by the Eq. (8):

$q_{t}=k_{p} t^{0.5}+C$

where, $q_{t}$ is the amount of phosphorus adsorbed at time $t(\mathrm{mg} / \mathrm{g}), q_{e}$ is the adsorption capacity at equilibrium $(\mathrm{mg} / \mathrm{g}), k_{1 p}$ is the pseudofirst order rate constant $\left(h^{-1}\right), k_{2 p}$ stands for the pseudo-second order rate constant $(\mathrm{g} / \mathrm{mg} / \mathrm{h}), k_{p}$ indicates the intra-particle diffusion rate constant $\left(\mathrm{mg} / \mathrm{g} / \mathrm{h}^{0.5}\right), C(\mathrm{mg} / \mathrm{g})$ is concerned with the boundary layer thickness, and $t$ is the contact time $(h)$. The kinetic model parameters were determined by nonlinear regression method, using Curve Expert Professional 2.0.4, and presented in Table 2. As shown in Table 2, the experimental $q_{e}$ values were all higher than corresponding results calculated by Pseudo-first order model. This demonstrates that the Pseudo-first order model could not predict the kinetic data accurately. Additionally, the experimental data obeyed the Pseudo-first order and Pseudo-second order models with correlation coefficients equal to or higher than 0.975 and 0.989, respectively. Evidently, Pseudo-second order model was more satisfactory than Pseudo-first order model in describing the experimental data. On the contrary, very poor correlation coefficients (0.439-0.879) were achieved with Weber-Morris diffusion model. In term of the correlation coefficient $\left(r^{2}\right)$, the fitness of three investigated kinetic models to experimental data was in the

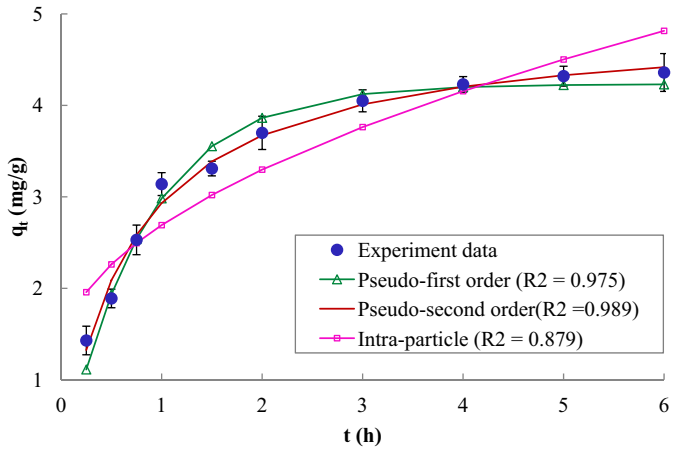

Fig. 4. The fitting of kinetic models to phosphorus biosorption onto ZLO $\left(C_{i} 50 \mathrm{mg}\right.$ $\mathrm{P} / \mathrm{L}$, dose $10 \mathrm{~g} / \mathrm{L}, 120 \mathrm{rpm}, 298 \mathrm{~K})$.

following order: Pseudo-second order $>$ Pseudo-first order $>$ Weber-Morris diffusion (Fig. 4). This finding implies that the chemisorption be probably an important pathway, while intraparticle diffusion could not be the dominant mechanism for the biosorption of phosphorus onto ZLO (Zhang et al., 2012). These results agreed well with those formerly reported by Jyothi et al. (2012), Mallampati and Valiyaveettil (2013) and Peng et al. (2012) in case of removal of phosphate with apple peels and biomass char, respectively.

Regarding the adsorption rates, it is worth pointing that, the rate constants of pseudo-first order and pseudo-second order models $\left(k_{1 p}, k_{2 p}\right)$ decreased with rising initial phosphorus concentration, whereas the rate constant of Weber-Morris diffusion model $\left(k_{p}\right)$ enhanced at higher initial phosphorus concentration. This is supported by Fig. 3a, which displays that the adsorption was faster at lower initial phosphorus concentration. Similar trends can be detected in the work performed by Mezenner and Bensmaili (2009). The authors attributed the latter trend to the intensifying diffusion in the solid caused by higher driving force. Table 2 also demonstrates that, the enhanced initial phosphorus concentration led to the increase of $C$ values.

\subsection{Adsorption thermodynamics}

The thermodynamic parameters for the biosorption of phosphorus onto ZLO were calculated from experimental data, using Van't Hoff and Arrhenius equations (Mezenner and Bensmaili, 2009):

$\Delta G^{\circ}=-R T \ln K_{d}$

$\ln K_{d}=-\frac{\Delta H^{\circ}}{R T}+\frac{\Delta S^{\circ}}{R}$

where, $K_{d}$ is the distribution coefficient of the adsorption process; $\Delta G^{\circ}, \Delta H^{\circ}$, and $\Delta S^{\circ}$ are the changes in Gibbs free energy $(\mathrm{J} / \mathrm{mol})$,

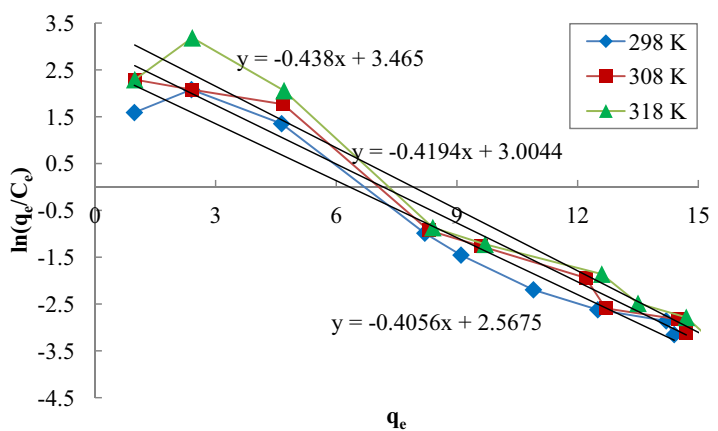

Fig. 5. Thermodynamic analysis for phosphorus biosorption onto ZLO $\left(C_{i}\right.$ $10 \div 500 \mathrm{mg} \mathrm{P} / \mathrm{L}$, dose $10 \mathrm{~g} / \mathrm{L}, 120 \mathrm{rpm}, 24 \mathrm{~h}, 298,308,318 \mathrm{~K})$ : A plot of $\ln \left(q_{e} / C_{e}\right)$ versus $q_{e}$. 
Table 3

Thermodynamic parameters for the biosorption of phosphorus onto ZLO.

\begin{tabular}{|c|c|c|c|c|c|c|}
\hline$T(K)$ & $q_{\max , \exp .}\left(\mathrm{mg} \mathrm{PO}_{4} / \mathrm{g}\right)$ & $K_{d}$ & $\Delta G^{\circ}(\mathrm{J} / \mathrm{mol})$ & $\Delta H^{\circ}(\mathrm{J} / \mathrm{mol})$ & $\Delta S^{\circ}(\mathrm{J} / \mathrm{mol} / \mathrm{K})$ & $R^{2}$ \\
\hline 298 & 44.13 & 2.567 & -2336 & 11814 & 47 & 0.999 \\
\hline 308 & 45.05 & 3.004 & -2817 & & & \\
\hline 318 & 46.27 & 3.465 & -3286 & & & \\
\hline
\end{tabular}

enthalpy $(\mathrm{J} / \mathrm{mol})$ and entropy $(\mathrm{J} / \mathrm{mol} / \mathrm{K})$, respectively; $T$ is the absolute temperature $(K)$; and $R$ is the gas constant $(8.314 \mathrm{~J} / \mathrm{mol} / \mathrm{K})$.

Initially, $K_{d}$ at a specific temperature was obtained by plotting $\ln \left(q_{e} / C_{e}\right)$ versus $q_{e}$, using linear regression type. The intercept of the plot represents the value of $K_{d}$ (Benyoucef and Amrani, 2011) (Fig. 5). Next, $\Delta G^{\circ}$ was calculated with the Eq. (9). Eventually, $\Delta H^{\circ}$ and $\Delta S^{\circ}$ were determined from the slope and intercept of the plot of $\ln K_{d}$ versus $1 / T$, using Eq. (10).

Table 3 represents thermodynamic parameters at different temperatures. The values of $\Delta G^{\circ}$ at $298,308,318 \mathrm{~K}$ were -2163 , -2675 , and $-3132 \mathrm{~J} / \mathrm{mol}$, respectively. The negative values of $\Delta G^{\circ}$ suggested that the biosorption of phosphorus onto ZLO be spontaneous and feasible. The $\Delta G^{\circ}$ declined from -2163 to $-3132 \mathrm{~J} / \mathrm{mol}$ when temperature increased from 298 to $318 \mathrm{~K}$, indicating an enhancement in phosphorus uptake at higher temperatures. This can be ascribed to the activation of ZLO surface by the temperature (Benyoucef and Amrani, 2011). The positive $\Delta H^{\circ}$ confirmed endothermic nature of the process (Kumar et al., 2010; Peng et al., 2012). The positive value of $\Delta S^{\circ}$ reflected good affinity of ZLO toward phosphate ions, and increasing randomness at the solidliquid interface during biosorption of phosphorus onto ZLO (Kumar et al., 2010; Mezenner and Bensmaili, 2009).

\section{Conclusion}

ZLO exhibited high capability for phosphorus purification from aqueous medium, owing to its wide effective $\mathrm{pH}$ range, reasonably high adsorption capacity, and extremely fast kinetics. The isotherm fitted properly Freundlich model. The Pseudo-second model was most suitable in describing the adsorption kinetics, implying the dominance of chemisorptions in the entire process. The negative value of $\Delta G^{\circ}$, the positive value of $\Delta H^{\circ}$, and the positive value of $\Delta S^{\circ}$ revealed the feasible, spontaneous and endothermic nature of the process. The research has provided a foundation for ZLO to be used as a green, affordable and competent biosorbent for phosphorus elimination.

\section{Acknowledgements}

The authors appreciate Sustainable Water Program - Theme of Wastewater Treatment and Reuse Technologies, Centre for Technology in Water and Wastewater (CTWW), School of Civil and Environmental Engineering, University of Technology, Sydney (UTS) and Australia Awards for granting the scholarship.

\section{References}

Anirudhan, T.S., Senan, P., 2011. Adsorption of phosphate ions from water using novel cellulose based adsorbent. J. Chem. Ecol. 27, 147-164.

Behnamfard, A., Salarirad, M.M., 2009. Equilibrium and kinetic studies on free cyanide adsorption from aqueous solution by activated carbon. J. Hazard. Mater. $170,127-133$

Benyoucef, S., Amrani, M., 2011. Adsorption of phosphate ions onto low cost Aleppo pine adsorbent. Desalination 275, 231-236.

Biswas, B.K., Inoue, K., Ghimire, K.N., Harada, H., Ohto, K., Kawakita, H., 2008. Removal and recovery of phosphorus from water by means of adsorption onto orange waste gel loaded with zirconium. Bioresour. Technol. 99, 8685-8690.

Biswas, B.K., Inoue, K., Ghimire, K.N., Ohta, S., 2007. The adsorption of phosphate from aquatic environment using metal loaded orange waste. J. Colloid Interface Sci. 312, 214-223.
Boujelben, N., Bouzid, J., Elouear, Z., Feki, M., Jamoussi, F., Montiel, A., 2008 Phosphorous removal from aqueous solution using iron coated natural and engineered sorbents. J. Hazard. Mater. 151, 103-110.

Carvalho, W.S., Martins, D.F., Gomes, F.R., Leite, I.R., Gustavo da Silva, L., Ruggiero, R., Richter, E.M., 2011. Phosphate adsorption on chemically modified sugarcane bagasse fibbers. Biomass Bioenergy 35, 3913-3919.

Choi, J., Lee, S., Kim, J., Park, K., Kim, D., Hong, S., 2012. Comparison of surface modified adsorbents for phosphate removal in water. Water Air Soil Pollut. 223, 2881-2890.

Cooper, J., Lombardi, R., Boardman, D., Marquet, C.C., 2011. The future distribution and production of global phosphate rock reserves. Resour. Conserv. Recycl. 57, 78-86.

De Lima, A.C.A., Nascimento, R.F., de Sousa, F.F., Filho, J.M., 2012. Modified coconut shell fibbers: a green and economical sorbent for the removal of anions from aqueous solutions. Chem. Eng. J. 185-186, 274-284.

Eberhardt, T.L., Min, S.H., 2008. Biosorbents prepared from wood particles treated with anionic polymer and iron salt: effect of particle size on phosphate adsorption. Bioresour. Technol. 99, 626-630.

Eberhardt, T.L., Min, S.H., Han, J.S., 2006. Phosphate removal by refined aspen wood fibber treated with carboxymethyl cellulose and ferrous chloride. Bioresour. Technol. 97, 2371-2376.

Eljamal, O., Okawauchi, J., Hiramatsu, K., Harada, M., 2013. Phosphorus sorption from aqueous solution using natural materials. Environ. Earth Sci. 68, 859863.

Han, J.S., Min, S.H., Kim, Y.K., 2005. Removal of phosphorus using AMD-treated lignocellulosic material. Forest Prod. J. 55, 48-53.

Ismail, Z.Z., 2012. Kinetic study for phosphate removal from water by recycled datepalm wastes as agricultural byproducts. Int. J. Environ. Stud. 69, 135-149.

Jyothi, M.D., Kiran, K.R., Ravindhranath, K., 2012. Phosphate pollution control in waste waters using new biosorbents. Int. J. Water Res. Environ. Eng. 4, $73-85$.

Karachalios, A.P., 2012. Nutrient Removal from Water by Various Quaternized Wood Agricultural Residues Using a Choline Based Ionic Liquid Analogue. Doctoral Dissertation, Stevens Institute of Technology, Castle Point Terrace, Hoboken, United States.

Krishnan, K.A., Haridas, A., 2008. Removal of phosphate from aqueous solutions and sewage using natural and surface modified coir pith. J. Hazard. Mater. 152, $527-$ 535.

Kumar, P., Sudha, S., Chand, S., Srivastava, V.C., 2010. Phosphate removal from aqueous solution using coir pith activated carbon. Separ. Sci. Technol. 45, 1463 1470.

Li, B., Qiao, M., Lu, F., 2012. Composition, nutrition, and utilization of okara (soybean residue). Food Rev. Int. 28, 231-252.

Loganathan, P., Vigneswaran, S., Kandasamy, J., Bolan, N.S., 2014. Removal and recovery of phosphate from water using sorption. Crit. Rev. Environ. Sci Technol. 44, 847-907.

Mallampati, R., Valiyaveettil, S., 2013. Apple peels - a versatile biomass for water purification. ACS Appl. Mater. Interfaces 5, 4443-4449.

Mezenner, N.Y., Bensmaili, A., 2009. Kinetics and thermodynamic study of phosphate adsorption on iron hydroxide-eggshell waste. Chem. Eng. J. 147, 87-96.

Nguyen, T.A.H., Ngo, H.H., Guo, W.S., Nguyen, T.V., Zhang, J., Liang, S., Chen, S.H., Nguyen, N.C., 2014. A comparative study on different metal loaded soybean milk by-product 'okara' for biosorption of phosphorus from aqueous solution. Bioresour. Technol. 169, 291-298. http://dx.doi.org/10.1016/j.biortech.2014.06. 075.

Nguyen, T.A.H., Ngo, H.H., Guo, W.S., Zhang, J., Liang, S., Tung, K.L., 2013. Feasibility of iron loaded 'okara' for biosorption of phosphorous in aqueous solutions. Bioresour. Technol. 150, 42-49.

Peleka, E.N., Deliyanni, E.A., 2009. Adsorptive removal of phosphates from aqueous solutions. Desalination 245, 357-371.

Peng, F., He, P., Luo, Y., Lu, X., Liang, Y., Fu, J., 2012. Adsorption of phosphate by biomass char deriving from fast pyrolysis of biomass waste. Clean - Soil Air Water 40, 493-498.

Riahi, K., Thayer, B.B., Mammou, A.B., Ammar, A.B., 2009. Biosorption characteristics of phosphates from aqueous solution onto Phoenix dactylifera L. date palm fibbers. J. Hazard. Mater. 170, 511-519.

Soy 20/20, 2005. Okara - Overview of current utilization. Available at <http:// www.soy2020.ca/pdfs/OverviewOfOkaraUtilization.pdf $>$ (accessed on April 21, 2014).

Wahab, M.A., Hassineb, R.B., Jellalia, S., 2011. Posidonia oceanica (L.) fibers as a potential low-cost adsorbent for the removal. J. Hazard. Mater. 191, 333-341.

Xu, X., Gao, B., Yue, Q., Zhong, Q., 2011a. Sorption of phosphate onto giant reed based adsorbent: FTIR, Raman spectrum analysis and dynamic sorption/ desorption properties in filter bed. Bioresour. Technol. 102, 5278-5282. 
Xu, X., Gao, Y., Gao, B., Tan, X., Zhao, Y.Q., Yue, Q., Wang, Y., 2011b. Characteristics of diethylenetriamine-crosslinked cotton stalk/wheat stalk and their biosorption capacities for phosphate. J. Hazard. Mater. 192, 1690-1696.

Xu, X., Gao, B.Y., Yue, Q.Y., Zhong, Q.Q., 2010. Preparation of agricultural by-product based anion exchanger and its utilization for nitrate and phosphate removal. Bioresour. Technol. 101, 8558-8564.
Yue, Q.Y., Wang, W.Y., Gao, B.Y., Xu, X., Zhang, J., Li, Q., 2010. Phosphate removal from aqueous solutions by adsorption on modified giant reed. Water Environ. Res. 82, 374-381.

Zhang, J., Shan, W., Ge, J., Shen, Z., Lei, Y., Wang, W., 2012. Kinetic and equilibrium studies of liquid phase adsorption of phosphate on modified sugarcane bagasse. J. Environ. Eng. 138, 252-258. 